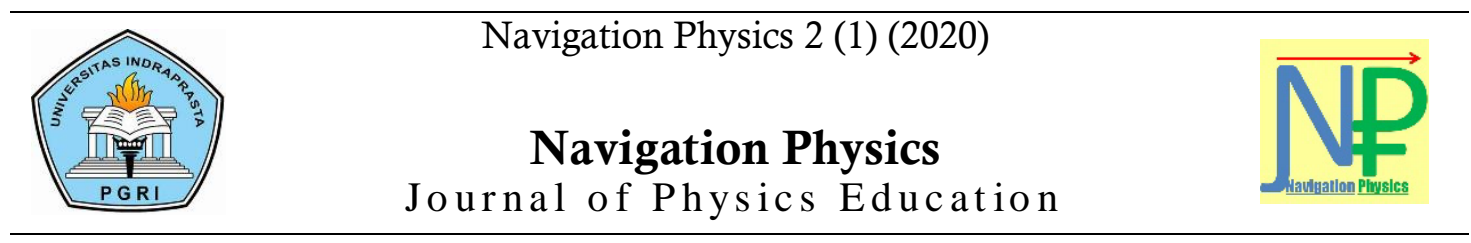

\title{
Pengembangan Media Pembelajaran Menggunakan Uno Stacko Pada Materi Fisika Kelas X
}

\author{
Siti Ayu Kumala ${ }^{1^{*}}$, Ria Asep Sumarni ${ }^{2}$, dan Fita Widiyatun ${ }^{3}$ \\ ${ }_{1,2,3}$ Universitas Indraprasta PGRI \\ * E-mail: sitikumala7891@gmail.com
}

\begin{tabular}{|c|c|}
\hline Info Artikel & Abstract \\
\hline $\begin{array}{l}\text { Sejarah Artikel: } \\
\text { Diterima April } 2020 \\
\text { Disetujui Mei } 2020 \\
\text { Dipublikasikan Juni } 2020 \\
\text { Keywords: } \\
\text { Learning media, UNO Stacko, } \\
\text { Physics. }\end{array}$ & $\begin{array}{l}\text { The UNO stacko game, is a game that is being loved by many people both } \\
\text { of children and adults. In this study, The UNO game that will be } \\
\text { developed is the UNO stacko game as a learning media. The UNO stacko } \\
\text { game consists of } 45 \text { stackos with various colors and various command } \\
\text { instructions. The colors in UNO stacko have five colors, including blue, } \\
\text { yellow, red, green, and purple. Each color block is filled with test questions } \\
\text { for understanding physics matter that are in accordance with the game } \\
\text { instructions. Validation tests are carried out by media experts and material } \\
\text { experts, where in each validation test there are several aspects tested. The } \\
\text { average results from the results of validation tests of media experts and } \\
\text { material experts regarding this interactive learning media were } 88.19 \% \text { and } \\
88.69 \% \text {. This percentage shows that interactive learning media that } \\
\text { researchers make is included in good criteria. So this media can be used as } \\
\text { a learning media that can be applied to physics learning for students. }\end{array}$ \\
\hline
\end{tabular}

How to Cite: Kumala, S. A., Sumarni, R.A., \& Widiyatun, F. (2020). Pengembangan media pembelajaran menggunakan Uno Stacko pada materi Fisika kelas X. Navigation Physics, 2 (1): 14-20.

\section{PENDAHULUAN}

Permainan edukasi merupakan salah satu cara untuk dapat membantu siswa dalam pemahaman konsep keilmuan. Pengembangan tentang permainan edukasi telah banyak dilakukan, baik dari berbagai permaian maupun sasaran ilmu pengetahuan yang akan dituju. Bahkan permainan edukasi berbasis game android pun telah ada (Kanday, 2017). Proses pembelajaran yang dibantu dengan suatu media akan cenderung mendapatkan hasil belajar yang baik. Berdasarkan hasil observasi, kegiatan pengayaan yang dilakukan masih kurang variatif. Untuk itu dibutuhkan media yang dapat digunakan untuk mendukung kegiatan pengayaan siswa (Pranata, 2017).

Menurut (Hidayati \& Hakim, 2014) menjelaskan bahwa Uno adalah salah satu permainan kartu keluarga yang paling terkenal di dunia dengan peraturan yang cukup mudah untuk siapapun di atas usia tujuh tahun. Jadi, permainan kartu Uno adalah barang yang berupa kertas tebal berbentuk persegi panjang yang digunakan untuk bermain pada usia di atas tujuh tahun. Kartu Uno merupakan kartu yang berasal dari Negara Italia. Kata Uno tersebut artinya adalah satu. Permainan Kartu Uno adalah permainan keluarga yang terdiri dari 108 kartu, bisa dimainkan 2 sampai 10 orang. Dimana permainannya dengan cara membedakan warna, gambar dan angka. 


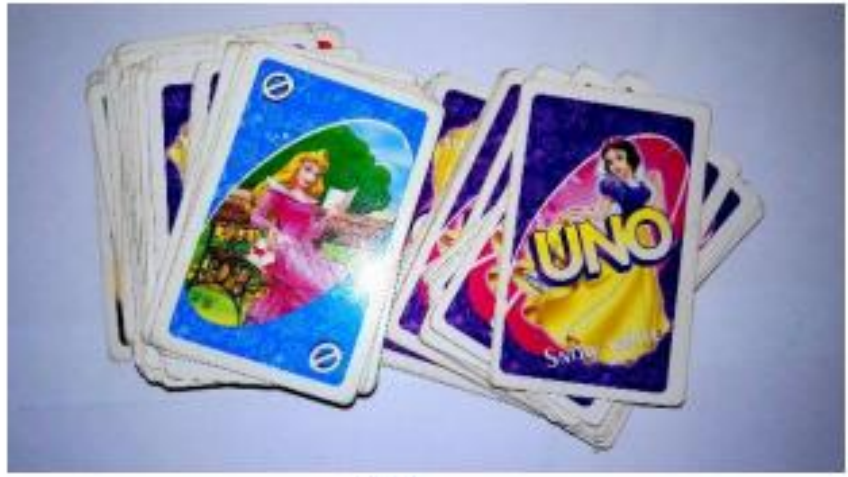

(a)

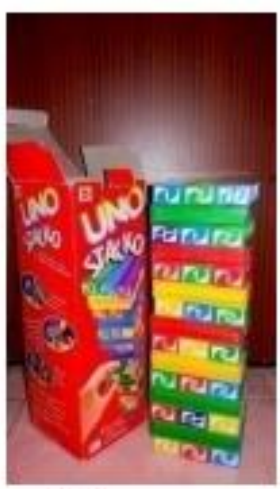

(b)

Gambar 1. Macam-macam UNO. (a) Uno card, dan (b) Uno Stacko (Asty,2016)

UNO Stacko adalah kombinasi dari kedua permainan kartu asli UNO dan permainan balok menara yaitu "Jenga". Antara dua sampai 10 pemain bergiliran menarik balok yang berbeda berwarna dari menara dan menempatkan mereka di atas itu sesuai dengan aturan permainan. Permainan berakhir ketika seseorang membuat jatuhnya menara . Uno Stacko diterbitkan oleh perusahaan mainan Mattel pada tahun 1999. Sebuah permainan dari Uno Stacko berlangsung sekitar 20 menit untuk bermain dari awal sampai akhir dan dianjurkan untuk usia 7 tahun ke atas. Prinsip permainan ini adalah menyamakan warna atau angka. Permainan ini lebih menarik dan asyik untuk dimainkan karena terdapat action figure yang mempunyai aturan khusus saat dimainkan (Larasati \& Prihatnani, 2018).

Uno Stacko adalah permainan yang memiliki aturan yang mirip dengan permainan kartu Uno tetapi dimainkan dengan cara yang berbeda. Permainan ini dapat dimainkan dengan 2 sampai 10 pemain dan dianjurkan untuk usia 7 tahun dan lebih tua. Bermain game ini pada permukaan yang datar untuk mencegah menara roboh dan goyah, jika pemain menarik balok dengan dua tangan dari menabrak pada gerakan sedikit. Dan jangan lupa untuk berteriak "UNO"\& pemain yang tadi menggunakan dua tangan itu harus menarik dua balok lagi (Asty, 2016).

Manfaat Uno Stacko menurut Asty (2016) bagi anak-anak/siswa adalah:

1. Meningkatkan Keterampilan Kognitif Keterampilan kognitif (cognitive skill) berkaitan dengan kemampuan untuk belajar dan memecahkan masalah. Dengan bermain Uno Stacko peserta didik akan mencoba memecahkan masalah yaitu menyusun balok secara teratur dan rapi.

2. Meningkatkan Keterampilan Motorik Halus Keterampilan motorik halus (fine motor skill) berkaitan dengan kemampuan peserta didik menggunakan otot-otot kecilnya khususnya tangan dan jari-jari tangan. Balok harus dapat tersusun membentuk bangunan dengan bagian balok disusun secara hati-hati dan perlahan.

3. Meningkatkan Keterampilan Sosial Keterampilan sosial berkaitan dengan kemampuan berinteraksi dengan orang lain. Uno Stacko dapat dimainkan secara perorangan. Namun Uno Stacko dapat pula dimainkan secara kelompok. Permainan yang dilakukan oleh peserta didik secara kelompok akan meningkatkan interaksi sosial peserta didik. Dalam kelompok, peserta didik akan saling menghargai, saling membantu dan berdiskusi satu sama lain.

4. Melatih daya ingat Membantu melatih logika peserta didik. Misalnya balok diletakkan secara teratur kemudian ada salah satu bagian yang hilang maka peserta didik akan berusaha untuk menentukan cara apapun agar susunan balok tersebut tidak jatuh.

5. Melatih kesabaran Bermain Uno Stacko membutuhkan ketekunan, kesabaran dan memerlukan waktu untuk berfikir dalam menyelesaikan tantangan.

6. Memperluas pengetahuan Peserta didik akan belajar banyak hal, warna, maupun bentuk. Pengetahuan yang diperoleh dari cara ini biasanya mengesankan bagi peserta didik dibandingkan yang dihafalkan. Peserta didik dapat belajar konsep dasar suatu materi yang dipelajari.

Penelitian ini merupakan pengembangan permainan UNO untuk mata pelajaran Fisika SMA. Konsep dan aturan dalam permainan UNO stacko seperti pada permainan UNO stacko seperti umumnya. Hanya saja, diberikan tambahan soal dan jawaban fisika di bagian pinggir dalam stacko UNO. Soal-soal yang diberikan merupakan soal-soal pada materi SMA kelas 10.

Sampai saat ini di Indonesia masih sangat sedikit yang mengembangkan media pembelajaran dari permainan Uno Stacko untuk materi fisika di SMA, oleh karena itu tinjauan mengenai penelitian yang relevan lebih banyak tentang pengembangan media pembelajaran dari Uno card, atau Uno Stacko dalam materi bidang studi lain. Lestari telah mengembangkan Uno Stacko untuk pembelajaran fisika pada materi 
kalor dan menyatakan bahwa Uno Stacko dapat meningkatkan kerja sama dan kemampuan berfikir kritis siswa dalam menyelesaikan persoalan Fisika dengan solusi yang tepat sasaran dan dapat disimpulkan bahwa media pembelajaran berbasis permainan UNO Stacko yang dibuat memenuhi kriteria sangat baik dan layak untuk digunakan dalam pembelajaran fisika (Lestari \& Purwandari, 2018).

Virgadi dkk. (Virgadi et al., 2018) melakukan penelitian eksperimen menggunakan Uno Stacko untuk meningkatkan hasil belajar siswa. Penelitian ini menggunakan desain pretest-posttest, yang dilakukan terhadap dua kelas yaitu kelas eksperimen dan kelas kontrol. Virgadi membuat kosakata bahasa Jepang yang direkatkan pada balok UNO. Berdasarkan hasil penelitian ditemukan bahwa permainan UNO Stacko dapat meningkatkan hasil belajar siswa dalam pembelajaran kosakata bahasa Jepang dibandingkan dengan hasil pembelajaran kosakata siswa dengan metode konvensional. Hal ini dapat dilihat dari nilai evaluasi dan selisih hasil pretest dan posttest kelas eksperimen mengalami peningkatan.

Menurut (Gustiasih, Festin, Widajati, 2016) bahwa model pembelajaran konstruktvisitik bermedia uno stacko mendukung anak dalam membangun pengetahuan yang baru dipahami dilingkungannya, anak tidak merasa bosan serta berpengaruh terhadap perkembangan kemampuan kognitif anak yang perlu diasah dan dikembangkan. Model pengembangan yang digunakan dalam penelitian ini adalah model ADDIE. Sesuai dengan namanya model desain pembelajaran ADDIE ada 5 tahap/langkah yaitu Analysis, Desain, Development, Implementation, dan Evaluation. Menurut hasil penelitian Rahwanti, dapat disimpulkan bahwa media pembelajaran uno statik dalam penerapan model pembelajaran snowball throwing materi turunan kelas XI dalam kategori baik dan layak digunakan atau dapat pula dikatakan valid tanpa revisi.

\section{METODE PENELITIAN}

Metode penelitian yang akan dilakukan adalah eksperimen dan pengembangan. Pengembangan yang dilakukan adalah pengembangan dari permainan Uno. Tiap balok diisi pertanyaan untuk menguji pemahaman siswa mengenai materi fisika kelas X. Adapun rancangan pengembangan media pembelajaran dari Uno stacko dapat terlihat pada gambar 2.

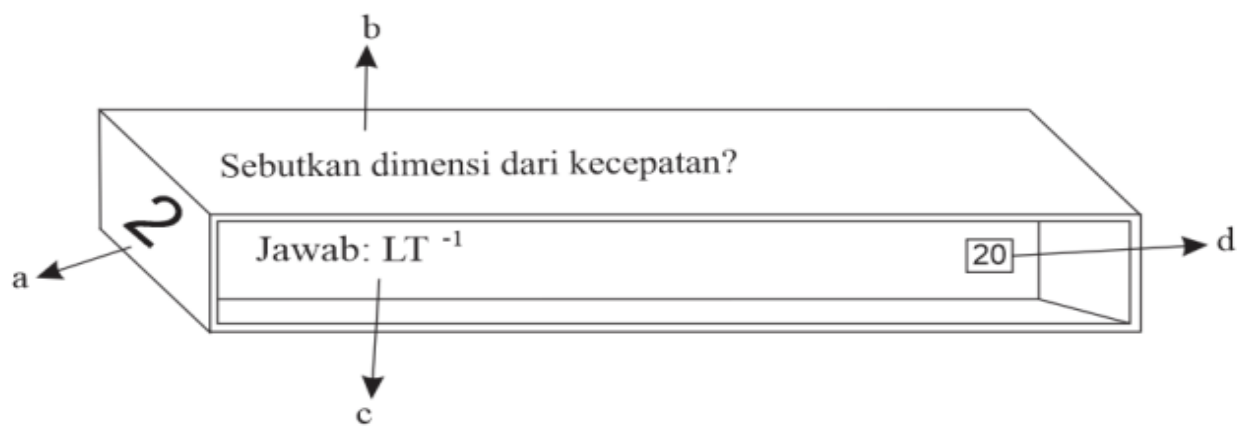

Gambar 2. Konsep gambar Uno permainan Fisika.

Keterangan pada gambar :

a. Sisi bagian berisikan aturan permainan untuk langkah selanjutnya

b. Sisi bagian yang akan berisikan soal fisika

c. Sisi bagian yang akan berisikan jawaban

d. Sisi bagian yang akan berisikan nilai/skor

Alat dan bahan yang digunakan dala penelitian ini diantaranya satu set permainan uno, kertas, lem, dan bullpen. Selain itu, untuk menulis soal di dalam balok permainan uno, juga diperlukan alat penyablon untuk balok tersebut. Materi soal yang dicantumkan dalam permainan uno ini adalah materi soal Fisika SMA kelas X. Materi-materi tersebut meliputi besaran dan satuan, vector, kinematika, dinamika, usaha dan energi, momentum dan impuls serta tumbukan. Masing-masing satu kotak Uno diberikan dua buah soal. Hal ini untuk mengantisipasi akan diambilnya kotak tersebut lebih dari dua kali. Selain soal, juga diberikan jawaban dari soal tersebut di sisi yang lainya.

Beberapa tahapan penelitian yang akan dilakukan dalam penelitian ini, diantaranya yaitu :

1. Analysis. Analisis awal yang dilakukan adalah studi literature Tim peneliti melakukan studi literature terhadap tema penelitian. Selain itu, mempelajari lebih lanjut tentang permainan Uno serta membaca referensi tentang game edukasi. 
2. Desain. Pembuatan desain penelitian dilakukan dalam nentuk pembuatan proposal penelitian. proposal penelitian. Desain meliputi model atau metode apa yang akan dipakai dalam penelitian termasuk alat dan bahan apa saja yang dipersiapkan dalam pembuatan media pembelajaran Uno stacko.

3. Development. Pada tahapan ini meliputi persiapan untuk persiapan soal dan jawaban yang akan dimasukan ke dalam balok permainan uno. Selain soal, juga dibuat juga penilaian untuk masingmasing soal. Semakin sulit standar soal yang dibuat, nilainya semakin besar.

selain persiapan soal, materi, dan nilai, juga dipersiapkan balok untuk persiapan uno yang akan dimodifikasi dengan penambahan soal fisika.

4. Setelah persiapan soal, jawaban, nilai dan balok Uno-nya, kemudian dilakukan penempelan soal pada balok Uno. Penempelan soal dilakukan dengan cara penyablonan pada balok Uno. Sedangakn jawaban dan nilai dilakukan dengan menuliskan jawaban pada kertas dan menempelkan jawaban tersebut dengan menggunakan lem.

5. Validasi alat. Pada bagian ini, validasi dilakukan oleh seorang ahli dibidang pendidikan Fisika maupu Fisika.

6. Hasil dari validasi menunjukkan layak tidaknya permainan tersebut, apabila layak maka aka lanjut ke tahap berikutnya. Tetapi, apabila belum sesuai atau belum layak maka akan kembali ke tahap persiapan alat dan bahan.

7. Hasil dari validasi kemudian dianalisis, sehingga diperoleh hasil dan kesimpulan.

Keseluruhan tahap penelitian digambarkan oleh gambar 3.

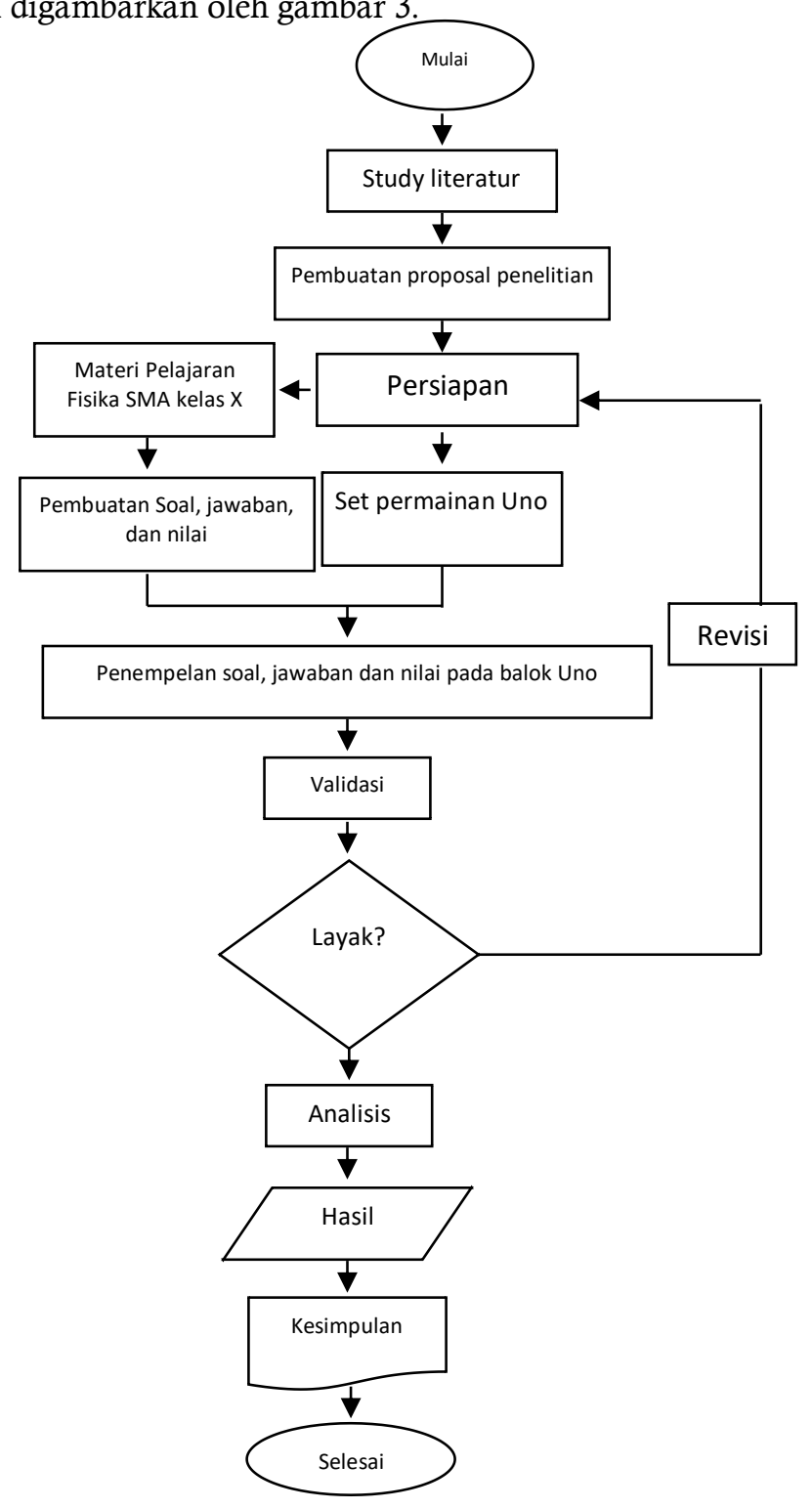

Gambar 3. Tahapan penelitian 


\section{HASIL DAN PEMBAHASAN}

Tahap pertama dalam pembuatan media pembelajaran interaktif dengan menggunakan uno stakco adalah dengan menentukan letak yang tepat dalam pemasangan soal pada balok uno. Selain menentukan lekat pemasangan soal, peneliti juga perlu memperhatikan ukuran huruf pada soal supaya tetap terbaca jelas pada saat dipasang di balok uno.

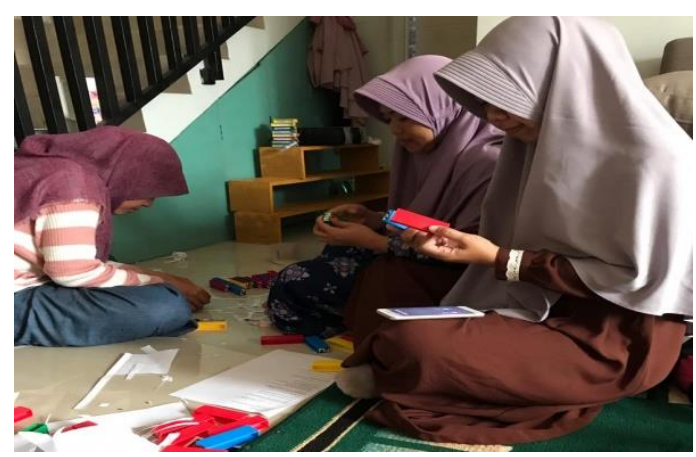

(a)

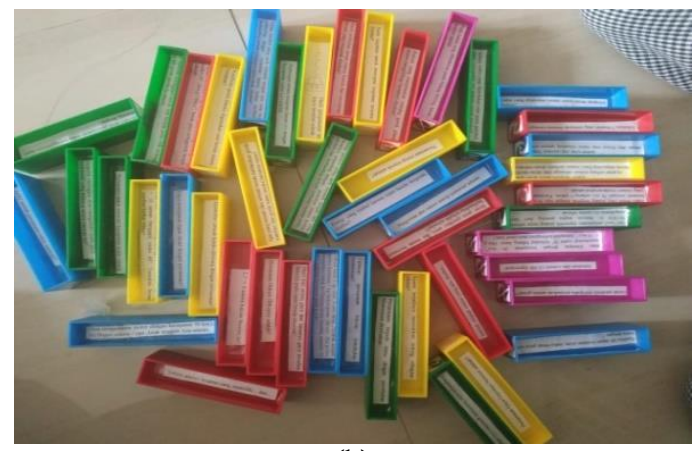

(b)

Gambar 4. Pemasangan Soal pada Balok Uno, (a) tim sedang membuat merangkai alat permaian UNO-nya, (b) balok permainan uno siap untuk digunakan.

Balok-balok Uno ditempel dengan soal materi fisika. Materi-materi tersebut meliputi besaran dan satuan, vektor, kinematika, dinamika, usaha dan energi, momentum dan impuls serta tumbukan. Pada masing masing balok sisi satunya ditempel dengan soal dan sisi lainnya ditempel skor nilai dari soal tersebut. Pembahasan dan jawaban soal dibuat terpisah dicetak di kertas selembar dari kertas bufallo, untuk mencocokkan jawaban benar atau salah. Media permainan uno stacko ini juga dilengkapi panduan yang memudahkan bagi pengguna untuk memahami aturan main media ini.

\section{Validasi}

Setelah selesai pembuatan media pembelajaran interaktif menggunakan permainan uno stacko, dilakukan uji validasi kepada ahli media dan ahli materi. Uji validasi ini dilakukan untuk mengetahui hasil dari evaluasi ahli media dan ahli materi, apakah media yang kami buat layak dan sesuai untuk digunakan sebagai media pembelajaran yang interaktif dan menarik

Validasi ahli media dan ahli materi dilakukan oleh dosen Informatika dan dosen Fisika Universitas Indraprasta PGRI. Hasil uji validasi ahli media dan ahli materi diperoleh hasil sebagai berikut:

Tabel 1. Hasil validasi ahli media

\begin{tabular}{cc}
\hline ASPEK & PRESENTASE (\%) \\
\hline Umum & 83,33 \\
Komunikasi Visual & 87,50 \\
Manfaat & 93,75 \\
Rata-rata & 88,19 \\
\hline
\end{tabular}


Hasil validasi ahli media mencakup tiga aspek, yaitu aspek umum, aspek komunikasi visual, dan aspek manfaat. Pada aspek umum diperoleh nilai persentase sebesar 83,33\%, aspek komunikasi visual diperoleh sebesar $87,50 \%$ dan pada aspek manfaat diperoleh $93,75 \%$. Diperoleh nilai rata-rata dari hasil uji validasi ahli media adalah sebeasar $88,19 \%$, sehingga hasil dari validasi ahli media masuk dalam kreteria baik.

Tabel 2. Hasil validasi ahli materi

\begin{tabular}{lc}
\hline Aspek & Presentase (\%) \\
\hline Pembelajaran & 78,57 \\
Soal & 95,83 \\
Bahasa & 91,67 \\
Rata-rata & 88,69 \\
\hline
\end{tabular}

Hasil validasi ahli materi mencakup tiga aspek, yaitu aspek pemebelajaran, aspek soal, dan aspek bahasa. Pada aspek pemebelajaran diperoleh nilai persentase sebesar 78,57\%, aspek soal diperoleh sebesar $95,83 \%$ dan pada aspek bahasa diperoleh $91,67 \%$. Diperoleh nilai rata-rata dari hasil uji validasi ahli materi adalah sebeasar $88,69 \%$, sehingga hasil dari validasi ahli materi masuk dalam kreteria baik. Sehingga media ini bisa digunakan sebagai media pembelajaran yang dapat diterapkan untuk pembelajaran fisika kepada siswa.

Permainan UNO stacko, merupakan permainan yang sedang banyak digandrungi oleh masyarakat. Baik dari kalangan anak-anak sampai dengan orang dewasa. Dalam penelitian ini, permainan UNO yang akan dikembangkan adalah permainan UNO stacko. Permainan UNO balik terdiri dari 45 stacko dengan berbagai warna dan berbagai petunjuk perintah. Warna di dalam stacko UNO terdapat lima warna, diantaranya biru, kuning, marah, hijau, dan ungu. Petunjuk penggunaan terlihat di bagian pinggir stacko, diantaranya ada tulisan stacko berangka, turn-around block, draw two block, skip block, dan wild block.

Media pembelajaran dengan menggunakan permainan UNO stacko yang telah peneliti buat dapat dijadikan salah satu alternatif media pembelajaran yang interaktif. Media ini dilengkapi dengan panduan dan kunci jawaban sehingga memudahkan pengguna dalam menggunakan. Media pembelajaran ini membuat pengguna jadi lebih mandiri dan berfikir lebih teliti, dikarenakan dalam permainan ini selain memainkan UNO stacko pengguna juga harus menjawab pertanyaan yang terdapat pada balok

\section{PENUTUP}

Hasil penelitian pembuatan media pembelajaran interaktif menggunakan permainan uno stacko menyatakan bahwa telah dibuat media pembelajaran interaktif menggunakan permainan uno stakco yang dapat digunakan dalam pembelajaran fisika Hasil dari uji validasi ahli media dan ahli materi mengenai media pembelajaran interaktif menggunakan permainan uno stakco termasuk dalam kriteria baik. Sehingga media ini dapat digunakan dalam kegitan belajar mengajar materi fisika.

Media pembelajaran yang peneliti buat tentunya masih bisa dikembangkan lagi untuk materi-materi fisika lainnya, yang tidak hanya meliputi beberapa bab saja. Sehingga saran dalam penelitian selanjutnya adalah agar permainan ini dapat diperbanyak soal dari berbagai macam materi fisika lainnya.

\section{DAFTAR PUSTAKA}

Asty, Z. F. (2016). Pengembangan Media Pembelajaran Uno Stacko padaMateri Klasifikasi Verterbrata untuk Siswa Kelas VII SMP. Skripsi. Universitas Jambi.

Gustiasih, Festin, Widajati, W. (2016). Pengaruh Model Pembelajaran Konstruktivistik Bermedia Uno Stacko Terhadap Kemampuan Mengenal Lambang Bilangan Anak Kelompok A. PAUD Teratai, Vol 5, No, $1-6$.

Hidayati, N., \& Hakim, L. (2014). Pengembangan Permainan Kartu UNO sebagai Alat Evaluasi Pembelajran Akuntansi Pokok Bahasan Hutang Jangka Panjang. Jurnal Pendidikan Akuntansi, 2(2), $1-11$.

Kanday, F. S. (2017). Game Edukasi Pengenalan Lagu Lagu Nasional Berbasis Mobile. J-Intech, 05(01). https://doi.org/10.1017/CBO9781107415324.004

Larasati, M. S., \& Prihatnani, E. (2018). Pengembangan Media Pembelajaran Ush (Uno Stacko Hitung). EDU-MAT: Jurnal Pendidikan Matematika, 6(2), 150-161.

https://doi.org/10.20527/edumat.v6i2.5679

Lestari, D., \& Purwandari. (2018). Pengembangan Permainan Uno Staco Sebagai Media Pembelajaran 
Untuk Meningkatkan Kerja Sama dan Kemampuan Berfikir Kritis Siswa Pada Materi Kalor Kelas XI TKR 1 SMKN 1 Jiwan. Prosiding Seminar Nasional Quantum, 25, 145-149.

Pranata, Y. (2017). Pengembangan Permainan Uno Stacko Akuntansi Sebagai Media Pengayaan Pada Pokok Bahasan Akuntansi Piutang Siswa Kelas Xi Smk Negeri Di Surabaya. JPAK UN Surabaya, Vol. 5 No.

Virgadi, F., Sinaga, M., \& Rahayu, N. (2018). Japanese Vocabulary Enhancement Through The Uno Stacko Game ( Experimental Research of Students of XI class SMA Muhammadiyah 1 Pekanbaru ). Jurnal Online Mahasiswa (JOM) Bidang Keguruan Dan Ilmu Pendidikan, 5(1), 112-121. 